\title{
Evolution of Technetium Speciation in Reducing Grout
}

Wayne W. Lukens, * Jerome J. Bucher, David K. Shuh, and Norman M. Edelstein

\author{
Actinide Chemistry Group \\ Chemical Sciences Division \\ Lawrence Berkeley National Laboratory \\ Berkeley, CA 94720
}

wwlukens@lbl.gov

\section{RECEIVED DATE (to be automatically inserted after your manuscript is accepted if required according to the journal that you are submitting your paper to)}

\begin{abstract}
Cementitious waste forms (CWFs) are an important component of the strategy to immobilize high-level nuclear waste resulting from plutonium production by the U.S. Department of Energy (DOE). Technetium $\left({ }^{99} \mathrm{Tc}\right)$ is an abundant fission product of particular concern in CWFs due to the high solubility and mobility of pertechnetate, $\mathrm{TcO}_{4}^{-}$, the stable form of technetium in aerobic environments. CWFs can more effectively immobilize ${ }^{99} \mathrm{Tc}$ if they contain additives that reduce mobile $\mathrm{TcO}_{4}{ }^{-}$to immobile $\mathrm{Tc}(\mathrm{IV})$ species. Leaching of ${ }^{99} \mathrm{Tc}$ from reducing CWFs that contain $\mathrm{Tc}(\mathrm{IV})$ is much slower than for CWFs containing $\mathrm{TcO}_{4}^{-}$. Previous X-ray absorption fine structure (XAFS) studies showed that he Tc(IV) species were oxidized to $\mathrm{TcO}_{4}{ }^{-}$in reducing grout samples prepared on a laboratory scale. Whether the oxidizer was atmospheric $\mathrm{O}_{2}$ or $\mathrm{NO}_{3}{ }^{-}$in the waste simulant was not determined. In actual CWFs, rapid oxidation of Tc(IV) by $\mathrm{NO}_{3}{ }^{-}$would be a concern, whereas oxidation by atmospheric $\mathrm{O}_{2}$ would be of less concern due to the slow diffusion and reaction of $\mathrm{O}_{2}$ with the reducing CWF. To address this uncertainty, two series of reducing grouts were prepared using $\mathrm{TcO}_{4}{ }^{-}$containing waste simulants with and without $\mathrm{NO}_{3}{ }^{-}$. In the first series of samples, the $\mathrm{TcO}_{4}{ }^{-}$was completely reduced using $\mathrm{Na}_{2} \mathrm{~S}$, and the samples were placed in containers that permitted $\mathrm{O}_{2}$ diffusion. In these samples, all of the technetium was initially present as a Tc(IV) sulfide compound, $\mathrm{TcS}_{\mathrm{x}}$, which was characterized using extended X-ray absorption fine structure (EXAFS)
\end{abstract}


spectroscopy, and is likely $\mathrm{Tc}_{2} \mathrm{~S}_{7}$. The $\mathrm{TcS}_{\mathrm{x}}$ initially present in the grout samples was steadily oxidized

over 4 years. In the second series of samples, all of the $\mathrm{TcO}_{4}^{-}$was not initially reduced, and the grout samples were placed in airtight containers. In these samples, the remaining $\mathrm{TcO}_{4}{ }^{-}$continued to be reduced as the samples aged, presumably due to the presence of reducing blast furnace slag. When samples in the second series were exposed to atmosphere, the lower-valent technetium species were rapidly oxidized to $\mathrm{TcO}_{4}^{-}$

KEYWORDS technetium, cement, grout, nuclear waste

BRIEFS The speciation of technetium in reducing grout samples was followed using X-ray absorption fine structure spectroscopy. The reduced technetium species were susceptible to oxidation by oxygen, but nitrate had no observable effect over the duration of the experiment.

\section{MANUSCRIPT TEXT}

Introduction Immobilization of the high-level nuclear waste created during plutonium production by the U.S. Department of Energy (DOE) is the most expensive and complex remediation project in the U. S. ${ }^{1,2}$ An important component of this effort is the use of grout based cementitious waste forms (CWFs) to immobilize the low-activity waste stream at the Savannah River Site and to stabilize the waste residues in high-level tanks at both the Savannah River and Hanford Sites. ${ }^{3-6}$ The long-term effectiveness of these measures to prevent the migration of radionuclides is described by performance assessments that depend on the leach rates of the radionuclides. ${ }^{3,5,7,8}{ }^{99} \mathrm{Tc}$ is one of the radionuclides of greatest concern for leaching from CWFs because of the high mobility and lack of sorption of pertechnetate, $\mathrm{TcO}_{4}^{-}$, the most stable form of technetium under aerobic conditions. ${ }^{8,9}$

For soluble contaminants such as $\mathrm{TcO}_{4}{ }^{-}$or $\mathrm{NO}_{3}{ }^{-}$, leach rates from $\mathrm{CWFs}$ can be modeled using an effective diffusion coefficient, $D_{\text {eff }}=N_{m} D_{m}$ where $D_{m}$ is the molar diffusion coefficient of the contaminant in water and $\mathrm{N}_{\mathrm{m}}$ is the MacMullin number, a characteristic of the porous solid that is identical for solutes such as gases or anions that are highly soluble and not adsorbed by the matrix. ${ }^{10}$ Among potential CWFs, $\mathrm{D}_{\text {eff }}\left(\mathrm{NO}_{3}{ }^{-}\right)$varies $1.3 \square 10^{-9} \mathrm{~cm}^{2} \mathrm{~s}^{-1}$ to $6.2 \square 10^{-8} \mathrm{~cm}^{2} \mathrm{~s}^{-1} .5,9,11$ The $\mathrm{D}_{\text {eff }}$ values for $\mathrm{NO}_{3}{ }^{-}$and $\mathrm{TcO}_{4}^{-}$are similar 
since their molar diffusion coefficients are almost identical, $1.53 \square 10^{-5}$ and $1.48 \square 10^{-5} \mathrm{~cm}^{2} \mathrm{~s}^{-1}$, respectively. ${ }^{12,13}$ The leachability of technetium can be greatly decreased by reducing soluble $\mathrm{TcO}_{4}{ }^{-}$to insoluble Tc(IV) species by the addition of blast furnace slag (BFS) or other reductants to the grout. The $\left.\mathrm{D}_{\text {eff }}{ }^{99} \mathrm{Tc}\right)$ values of reducing grouts are much smaller, $3 \square 10^{-11} \mathrm{~cm}^{2} \mathrm{~s}^{-1}$ to $4 \square 10^{-12} \mathrm{~cm}^{2} \mathrm{~s}^{-1}$, because Tc(IV) how low solubility and readily sorbs to the grout matrix. ${ }^{9,11}$ Reducing conditions used in actual CWFs take advantage of this decreased leachability to create a more effective waste form. ${ }^{6,11}$

A previous research study showed that although $\mathrm{TcO}_{4}{ }^{-}$is reduced to $\mathrm{Tc}(\mathrm{IV})$ in reducing grouts, the degree of reduction varied with experimental conditions. ${ }^{14}$ In some cases, $\mathrm{TcO}_{4}{ }^{-}$was initially reduced to Tc(IV) but was later oxidized. Two species, $\mathrm{NO}_{3}{ }^{-}$and $\mathrm{O}_{2}$, are present in large quantities in or around CWFs and are potentially capable of oxidizing $\mathrm{Tc}(\mathrm{IV})$ to $\mathrm{TcO}_{4}{ }^{-}$. Whether $\mathrm{NO}_{3}{ }^{-}$or $\mathrm{O}_{2}$ is responsible for oxidizing Tc(IV) has a profound effect on the behavior and immobilization of technetium in CWFs.

Oxidation by $\mathrm{NO}_{3}{ }^{-}$or $\mathrm{O}_{2}$ produces two very different scenarios for the speciation and leaching of technetium from reducing CWFs. If $\mathrm{NO}_{3}{ }^{-}$is chiefly responsible for the oxidation, $\mathrm{Tc}(\mathrm{IV})$ would be oxidized throughout the entire CWF increasing the leachability of ${ }^{99} \mathrm{Tc}$ in the entire volume of the waste. In this scenario, the rate of oxidation of $\mathrm{Tc}(\mathrm{IV})$ to $\mathrm{TcO}_{4}{ }^{-}$would depend only on the reaction rate and the concentration of the reactants.

The scenario involving oxidation by $\mathrm{O}_{2}$ is more complicated. In this case, diffusion of $\mathrm{O}_{2}$ into the CWF would result in the formation oxidized surface region that would have greater technetium leachability. However, the leachability of technetium in the bulk of the waste would be unchanged since it would remain Tc(IV). As shown by Smith and Walton, the thickness of the oxidized region depends mainly upon $\mathrm{N}_{\mathrm{m}}$ and the reductive capacity of the CWF. ${ }^{15}$ Using typical parameters for reducing CWFs, the thickness of the oxidized region is small compared to the dimensions of the CWF, and oxidation by $\mathrm{O}_{2}$ is less of a concern than oxidation by $\mathrm{NO}_{3}^{-}$.

Therefore, the primary concern raised by the rapid oxidation of Tc(IV) species observed in the previous study was that $\mathrm{NO}_{3}{ }^{-}$rather than $\mathrm{O}_{2}$ was responsible for the oxidation. Such rapid oxidation of Tc(IV) by 
$\mathrm{NO}_{3}{ }^{-}$would mean that all of the initially reduced technetium in actual CWFs would be quickly oxidized back to $\mathrm{TcO}_{4}^{-}$. In this paper, the evolution of ${ }^{99} \mathrm{Tc}$ speciation in a series of grout samples both sealed and unsealed and with and without $\mathrm{NO}_{3}{ }^{-}$was followed for an extended period by $\mathrm{X}$-ray absorption fine structure (XAFS) to determine whether $\mathrm{NO}_{3}{ }^{-}$or $\mathrm{O}_{2}$ was responsible for oxidizing $\mathrm{Tc}(\mathrm{IV})$ species in these grout samples.

\section{Experimental}

Procedures Caution: ${ }^{99} \mathrm{Tc}$ is a Gemitter $\left(E_{\max }=294 \mathrm{keV}, \square_{/ 2}=2 \square 10^{5}\right.$ years $)$. All operations were carried out in a radiochemical laboratory equipped for handling this isotope. Technetium, as $\mathrm{NH}_{4}{ }^{99} \mathrm{TcO}_{4}$, was obtained from Oak Ridge National Laboratory. The solid $\mathrm{NH}_{4}{ }^{9}{ }^{9} \mathrm{TcO}_{4}$ was contaminated with a large amount of dark, insoluble material. Prolonged treatment of this sample with $\mathrm{H}_{2} \mathrm{O}_{2}$ and $\mathrm{NH}_{4} \mathrm{OH}$ did not appreciably reduce the amount of dark material. $\mathrm{NH}_{4} \mathrm{TcO}_{4}$ was separated by carefully decanting the colorless solution from the dark solid. A small amount of $\mathrm{NaOH}$ was added to the colorless solution, and the volatile components were removed under vacuum. The remaining solid was dissolved in water, and the colorless solution was removed from the remaining precipitate with a cannula. The concentration of $\mathrm{NaTcO}_{4}$ was determined spectrophotometrically at $289 \mathrm{~nm}\left(\square=2380 \mathrm{M} \mathrm{l}^{-1} \mathrm{~cm}^{-1}\right) .{ }^{16} \mathrm{UV}$-visible spectra were obtained using an Ocean-Optics ST2000 spectrometer.

All operations were carried out in air. Water was deionized, passed through an activated carbon cartridge to remove organic material and then distilled. All other chemicals were used as received. The grout samples examined here are similar to those previously used for the study of chromium reduction in reducing grout samples and are similar to Saltstone, the CWF used to immobilize low activity waste at the Savannah River Site. ${ }^{11,17}$ The dry cement consisted of 46\% Type F fly ash, 46\% BFS, and 8\% Portland cement. ${ }^{17}$ The fly ash, BFS, and Portland cement are those used by the Savannah River Saltstone facility, and were provided by C. A. Langton. Two series of grout samples were prepared.

The first series was prepared using solutions with and without $\mathrm{NO}_{3}{ }^{-}$and $\mathrm{NO}_{2}{ }^{-}$as shown in Table 1 . To the waste simulant was added $\mathrm{TcO}_{4}{ }^{-}\left(0.02 \mathrm{mmol}, 0.1 \mathrm{~mL}, 0.2 \mathrm{M} \mathrm{NH}_{4} \mathrm{TcO}_{4}\right)$, which was then reduced with $\mathrm{Na}_{2} \mathrm{~S}\left(0.21 \mathrm{mmol}, 0.1 \mathrm{~mL}, 2.1 \mathrm{M} \mathrm{Na} \mathrm{S}_{2} \mathrm{~S}\right)$ in $1 \mathrm{M} \mathrm{LiOH}$ forming a very dark solution with a black precipitate. 
The dry cement mixture was added forming a slurry that was placed in a polystyrene (PS) cuvette, which was capped and closed with vinyl tape and sealed inside two thin-walled polyethylene (PE) bags. This first series of samples will be referred to as "unsealed samples", and the final composition of the waste solution after addition of the $\mathrm{TcO}_{4}{ }^{-}$and $\mathrm{Na}_{2} \mathrm{~S}$ solutions is listed in Table 1.

The second series of samples was prepared analogously to the first. To the waste simulant was added $\mathrm{TcO}_{4}^{-}\left(0.012 \mathrm{mmol}, 0.30 \mathrm{~mL}, 0.039 \mathrm{M} \mathrm{NaTcO}_{4}\right)$ and an oxidized $\mathrm{Na}_{2} \mathrm{~S}$ solution in $1 \mathrm{M} \mathrm{LiOH}(0.065 \mathrm{~mL})$, which formed a dark solution with a black precipitate. The dry cement mixture was added, forming a slurry that was placed in an acrylic cuvette that was sealed with a plug of epoxy and further sealed inside two heavy-walled (PE) bags. This second series of samples will be referred to as "sealed samples", and the final composition of the waste solution after addition of the $\mathrm{TcO}_{4}{ }^{-}$and $\mathrm{Na}_{2} \mathrm{~S}$ solutions is also listed in Table 1. Samples A and C were opened after 26 months and placed in loosely capped jars that were opened weekly. Sample B remained sealed throughout the experiment.

Table 1: Composition of cement samples

\begin{tabular}{|c|c|c|c|c|}
\hline Sample & $\begin{array}{c}\mathrm{Tc} \\
(\mathrm{mg})\end{array}$ & $\begin{array}{l}\text { Solution } \\
(\mathrm{ml})\end{array}$ & Final Solution Composition & $\begin{array}{c}\text { Cement } \\
\text { (g) }\end{array}$ \\
\hline \multicolumn{5}{|c|}{ Unsealed Samples } \\
\hline 1 & 2 & 1.5 & $\begin{array}{c}\text { 1.85M NaNO} \mathrm{M} \mathrm{Na}_{3}, 1.07 \mathrm{M} \mathrm{NaOH}, 0.57 \mathrm{M} \mathrm{NaNO}_{2}, \\
0.23 \mathrm{M} \mathrm{NaAl}(\mathrm{OH})_{4}, 0.16 \mathrm{M} \mathrm{Na}_{2} \mathrm{CO}_{3}, 0.14 \mathrm{M} \mathrm{Na}_{2} \mathrm{SO}_{4}, \\
0.02 \mathrm{M} \mathrm{NaCl}, 0.02 \mathrm{M} \mathrm{Na}_{2} \mathrm{C}_{2} \mathrm{O}_{4}, 0.008 \mathrm{M} \mathrm{Na}_{3} \mathrm{PO}_{4}, \\
0.13 \mathrm{M} \mathrm{Na}_{2} \mathrm{~S}\end{array}$ & 3 \\
\hline 2 & 2 & 1.5 & As Sample 1 , but no $\mathrm{NaNO}_{3}, \mathrm{NaNO}_{2}$ & 3 \\
\hline 3 & 2 & 0.95 & As Sample 1 , but $0.05 \mathrm{M} \mathrm{Na}_{3} \mathrm{PO}_{4}$ & 1.5 \\
\hline 4 & 2 & 0.95 & As Sample 2, but $0.05 \mathrm{M} \mathrm{Na}_{3} \mathrm{PO}_{4}$ & 1.5 \\
\hline \multicolumn{5}{|c|}{ Sealed Samples } \\
\hline A & 1.2 & 0.66 & $2 \mathrm{M} \mathrm{NaOH}, 2 \mathrm{M} \mathrm{NaCl}$ & 1.0 \\
\hline B & 1.2 & 0.66 & $2 \mathrm{M} \mathrm{NaOH}, 2 \mathrm{M} \mathrm{NaNO}_{3}$ & 1.0 \\
\hline $\mathrm{C}$ & 1.2 & 0.66 & $2 \mathrm{M} \mathrm{NaOH}, 2 \mathrm{M} \mathrm{NaNO}_{2}$ & 1.0 \\
\hline
\end{tabular}


The reductive capacity of the BFS was determined using a slightly modified version of the Angus and Glasser method. ${ }^{18}$ The BFS $(\sim 0.5 \mathrm{~g})$ was slurried in $5-10 \mathrm{~mL}$ of water to which was added $25.0 \mathrm{~mL}$ of $0.059 \mathrm{M}\left(\mathrm{NH}_{4}\right)_{4} \mathrm{Ce}\left(\mathrm{SO}_{4}\right)_{4} \cdot 2 \mathrm{H}_{2} \mathrm{O}$ in $2 \mathrm{M}$ sulfuric acid. After 1 hour, the solution was titrated with freshly prepared $0.050 \mathrm{M}\left(\mathrm{NH}_{4}\right)_{2} \mathrm{Fe}\left(\mathrm{SO}_{4}\right)_{2} \cdot 6 \mathrm{H}_{2} \mathrm{O}$ in $0.75 \mathrm{M}$ sulfuric acid. The end point was determined using $0.25 \mathrm{~mL}$ of $0.025 \mathrm{M} \mathrm{Fe}(\mathrm{II})$ tris-(1,10-phenanthroline) complex. ${ }^{19,20}$ The reductive capacity of the BFS sample was $0.82(1) \mathrm{meq}^{-1}$ as determined from the difference in the volume of Fe(II) solution needed to titrate $25.0 \mathrm{~mL}$ of the $\mathrm{Ce}(\mathrm{IV})$ solution alone and with the BFS.

XAFS spectra were acquired at the Stanford Synchrotron Radiation Laboratory (SSRL) at Beamline 4-1 using a $\mathrm{Si}(220)$ double crystal monochromator detuned $50 \%$ to reduce the higher order harmonic content of the beam. All ${ }^{99} \mathrm{Tc}$ samples were triply contained inside sealed polyethylene vessels. X-ray absorption spectra were obtained in fluorescence yield mode using a multi-pixel Ge-detector system. ${ }^{21}$ The spectra were energy calibrated using the first inflection point of the $\mathrm{Tc} \mathrm{K}$-edge spectrum of $\mathrm{TcO}_{4}{ }^{-}$adsorbed on Reillex-HPQ ${ }^{\mathrm{TM}}$ anion exchange resin defined as $21044 \mathrm{eV}$. To determine the Tc K-edge absorption energies, the energies of the Tc K-edges at half height were used. EXAFS data analysis was performed by standard procedures $^{22}$ using the EXAFSPAK suite of programs developed by G. George of SSRL as previously described. ${ }^{23}$

The X-ray absorption near edge structure (XANES) spectra were fit using the spectra of $\mathrm{TcS}_{\mathrm{x}}, \mathrm{TcO}_{4}^{-}$, and $\mathrm{TcO}_{2} \cdot 2 \mathrm{H}_{2} \mathrm{O}$ as standards. The fitting was done using the code "fites" developed by C. H. Booth. ${ }^{24}$ The fit used 4 parameters and the XANES spectra had 19 independent data points ( $8 \mathrm{eV}$ resolution).

The determination of the thickness of the oxidized region in samples exposed to atmosphere was carried out using the probability of detecting an X-ray photon from within a sample as described by Tröger et al. ${ }^{25}$ The contribution, $c$, of a surface region of thickness, $d$, to the total fluorescent XANES signal is given in Eq 1, where $\square(\mathrm{E})$ and $\square(\mathrm{F})$ are the total absorption coefficients of the sample at the incident photon energy and the fluorescent photon energy, respectively, and $\square$ and $\square$ are the angles of the sample with respect to the incident photon beam and the fluorescent detector, respectively. For these experiments, $\square(\mathrm{E})$ and $\square(\mathrm{F})$ are 
5.3 and $7.8 \mathrm{~mm}^{-1}$, respectively, and were determined from the elemental composition of CWF given by Serne, et al. ${ }^{5}$

$$
c=\frac{1}{K} \square_{0}^{d}{ }^{\square K x} d x \quad K=\frac{\square(E)}{\sin \square}+\frac{\square(F)}{\sin \square}
$$

\section{Results and Discussion}

As discussed in the experimental section, two series of cement samples, "sealed" and "unsealed" were prepared. The speciation of technetium in these samples was determined using XAFS as the samples aged over a period of 4 years.

EXAFS studies of initial technetium speciation. A prerequisite for investigating the long-term behavior of technetium is identifying which technetium species are present. While it is obvious that $\mathrm{TcO}_{4}^{-}$ will be present under oxidizing conditions, ${ }^{16}$ the species present in grout under reducing conditions are less obvious. The hydrous $\mathrm{Tc}(\mathrm{IV})$ oxide, $\mathrm{TcO}_{2} \bullet \mathrm{xH}_{2} \mathrm{O}$, results from the reduction of $\mathrm{TcO}_{4}{ }^{-}$in the absence of other ligands both in solution and in grout samples. ${ }^{14,26}$ In addition, sulfide, either added to the grout as $\mathrm{Na}_{2} \mathrm{~S}$ or BFS, reduces $\mathrm{TcO}_{4}{ }^{-}$to a lower-valent technetium sulfide species thought to be similar to $\mathrm{TcS}_{2}{ }^{14}$ Interestingly, the reaction of sulfide with $\mathrm{TcO}_{4}{ }^{-}$in alkaline solution is a known route to $\mathrm{Tc}_{2} \mathrm{~S}_{7}{ }^{27}$ which is generally believed to be the technetium species present in reducing CWFs. ${ }^{15,27}$ While these results appear to be contradictory, the inconsistency is largely due to the Tc(VII) oxidation state implied by the stoichiometry of $\mathrm{Tc}_{2} \mathrm{~S}_{7}$. If $\mathrm{Tc}_{2} \mathrm{~S}_{7}$ is not actually a $\mathrm{Tc}(\mathrm{VII})$ sulfide complex but a lower-valent disulfide complex, no contradiction exists between these previous studies. Although $\mathrm{Tc}_{2} \mathrm{~S}_{7}$ is generally assumed to be a Tc(VII) compound, this assumption has never been examined. ${ }^{13}$

To identify the technetium sulfide species present in reducing grouts, the Tc K-edge EXAFS spectra of the unsealed samples were examined shortly after they were prepared. Only these samples contained a single technetium species. All other samples, including these samples at later times, contained more than 
one technetium species. The unsealed samples initially had identical Tc K-edge EXAFS spectra, as shown in Figure 1. The parameters derived by fitting the spectra, listed in Table 2, are also comparable. Therefore, in addition to containing only one technetium species, all of these samples contain the same technetium species, which will be termed $\mathrm{TcS}_{\mathrm{x}}$.

Table 2: Initial technetium coordination environment in the unsealed samples

\begin{tabular}{cccccc}
\hline $\begin{array}{c}\text { Scattering } \\
\text { Atom }\end{array}$ & \multicolumn{5}{c}{ Sample } \\
\hline \multirow{3}{*}{$\mathrm{S}$} & $\mathrm{N}$ & $7.4(2)$ & $7.9(2)$ & $7.3(2)$ & 4 \\
& $\mathrm{R}$ & $2.367(2)$ & $2.364(2)$ & $2.371(2)$ & $2.367(2)$ \\
& $\square^{2}$ & $0.0108(4)$ & $0.0115(3)$ & $0.0111(3)$ & $0.0121(3)$ \\
$\mathrm{Tc}$ & $\mathrm{N}$ & $2.1(1)$ & $2.0(2)$ & $2.0(2)$ & $2.0(2)$ \\
& $\mathrm{R}$ & $2.767(2)$ & $2.766(2)$ & $2.774(2)$ & $2.770(2)$ \\
& $\square^{2}$ & $0.0073(6)$ & $0.0071(4)$ & $0.0074(4)$ & $0.0071(4)$ \\
$\mathrm{Tc}$ & $\mathrm{N}$ & $0.22(8)$ & $0.25(4)$ & $0.24(4)$ & $0.25(5)$ \\
& $\mathrm{R}$ & $3.82(2)$ & $3.841(9)$ & $3.840(9)$ & $3.87(1)$ \\
& $\square^{2}$ & $0.003(1)$ & $0.0023(5)$ & $0.0023(5)$ & $0.0023(6)$ \\
$\mathrm{Tc}$ & $\mathrm{N}$ & $0.78^{\mathrm{a}}$ & $0.75^{\mathrm{a}}$ & $0.76^{\mathrm{a}}$ & $0.75^{\mathrm{a}}$ \\
& $\mathrm{R}$ & $4.28(1)$ & $4.295(7)$ & $4.291(1)$ & $4.317(8)$ \\
& $\square^{2}$ & $0.003^{\mathrm{a}}$ & $0.0023^{\mathrm{a}}$ & $0.0023^{\mathrm{a}}$ & $0.0023^{\mathrm{a}}$ \\
& & & & & \\
$\mathrm{S}$ & $\mathrm{N}$ & $2.5(5)$ & $2.9(3)$ & $2.5(3)$ & $2.7(4)$ \\
& $\mathrm{R}$ & $4.41(2)$ & $4.44(1)$ & $4.44(1)$ & $4.47(1)$ \\
& $\square^{2}$ & $0.005^{\mathrm{b}}$ & $0.005^{\mathrm{b}}$ & $0.005^{\mathrm{b}}$ & $0.005^{\mathrm{b}}$ \\
& & & & $-9.9(3)$ & $-9.7(4)$ \\
\hline
\end{tabular}

a) Parameter determined by the corresponding parameter in the preceding shell.

b) Parameter fixed. 

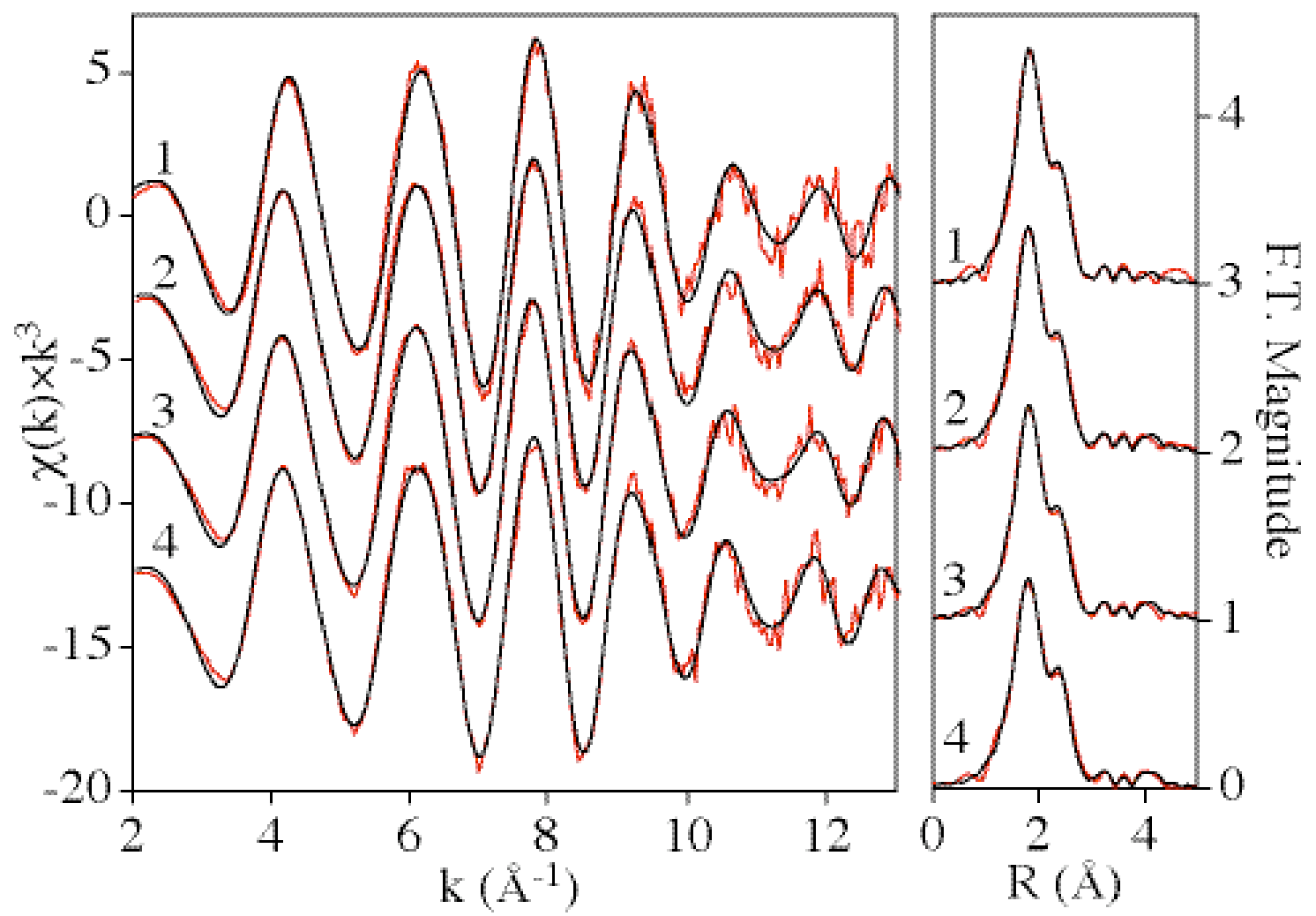

Figure 1: Tc K-edge EXAFS spectra (left) and their Fourier transforms (right) of the technetium species initially present in grouts prepared by initially reducing the $\mathrm{TcO}_{4}^{-}$with excess sodium sulfide. Data is shown in red and the fits are shown in black. Sample numbers are indicated next to the traces.

The coordination environment of $\mathrm{TcS}_{\mathrm{x}}$ can be described by considering the first two and last three coordination shells separately. The first two coordination shells, which comprise the large feature in the Fourier transformed EXAFS spectra, consist of $\sim 7$ sulfur neighbors at $2.37 \AA$ and 2 technetium nearest neighbors at $2.77 \AA$. These distances and coordination numbers are similar to those of the molybdenum sulfide complex, $\mathrm{Mo}_{3} \mathrm{~S}\left(\mathrm{~S}_{2}\right)_{6}{ }^{2-}$, shown in Figure 2, in which each molybdenum center has 7 sulfur and 2 molybdenum neighbors at 2.44 and $2.72 \AA$, respectively. ${ }^{28}$ The $\mathrm{Mo}_{3}\left(\square^{3}-\mathrm{S}\right)\left(\square-\mathrm{S}_{2}\right)_{3}$ core of this complex forms the building block of the $\mathrm{MoS}_{3}$ structure, ${ }^{29}$ which has an EXAFS spectrum similar to that of $\operatorname{TcS}_{\mathrm{x}} \cdot{ }^{30,31}$ The nearest neighbor environments in both compounds are analogous; in $\mathrm{MoS}_{3}$, each molybdenum center has $\sim 6$ sulfur neighbors at $2.44 \AA$ and 2 molybdenum neighbors at $2.75 \AA$. The similarities of the distances and coordination numbers of the first two coordination shells of $\mathrm{MoS}_{3}$, $\mathrm{Mo}_{3} \mathrm{~S}\left(\mathrm{~S}_{2}\right)_{6}{ }^{2-}$ and $\mathrm{TcS}_{\mathrm{x}}$ strongly suggest that the $\mathrm{TcS}_{\mathrm{x}}$ structure is built from the same triangular core, $\mathrm{Tc}_{3}\left(\square^{3}-\mathrm{S}\right)\left(\square-\mathrm{S}_{2}\right)_{3}$ as shown in Figure 2, with two additional sulfur-based ligands linking adjacent triangular 
clusters. Furthermore, the $2.77 \AA$ Tc-Tc distance is typical for such a triangular complex composed of seven-coordinate metal centers; analogous triangular complexes with six-coordinate metal centers have substantially shorter metal-metal distances. ${ }^{32}$

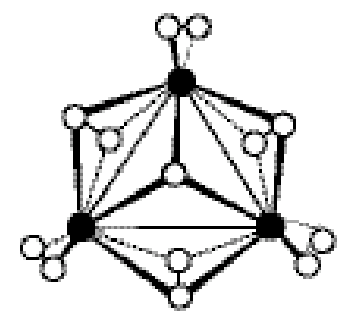

$\mathrm{Mo}_{3} \mathrm{~S}\left(\mathrm{~S}_{2}\right)_{6}{ }^{2-}$

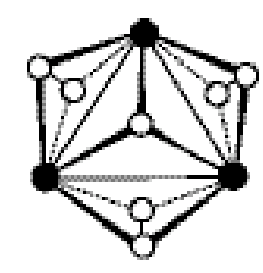

$\mathrm{Tc}_{3} \mathrm{~S}\left(\mathrm{~S}_{2}\right)_{3}$ core

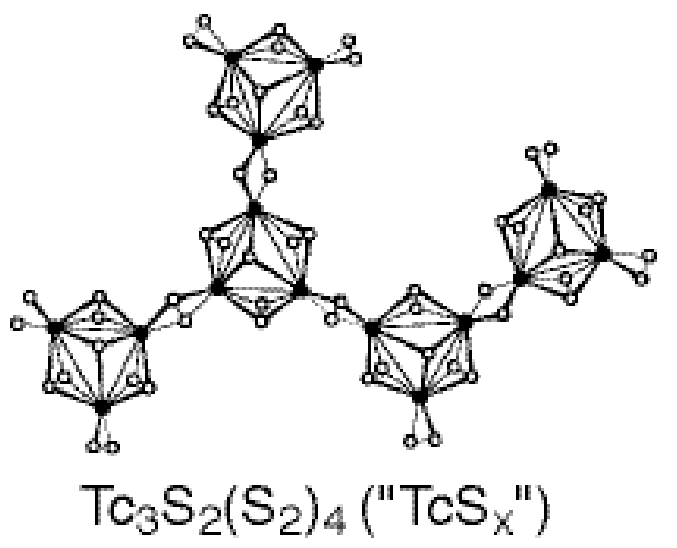

Figure 2: Structures of $\mathrm{Mo}_{3} \mathrm{~S}\left(\mathrm{~S}_{2}\right)_{6}{ }^{2-}$ and the analogous $\mathrm{Tc}_{3} \mathrm{~S}\left(\mathrm{~S}_{2}\right)_{3}$ core that forms the building block of $\mathrm{TcS}_{\mathrm{x}}$ metal atoms are illustrated by solid circles, sulfur atoms are illustrated by open circles.

The last three coordination shells, which form the small features at higher $\mathrm{R}$ in the Fourier transform, result from the next nearest neighbors of the technetium center. Each technetium has a next-nearest technetium neighbor at either $3.85 \AA(\sim 25 \%$ of the technetium centers $)$ or $4.3 \AA(\sim 75 \%$ of the technetium centers), and has $\sim 3$ additional sulfur neighbors at $4.4 \AA$ due to ligands on adjacent Tc centers. The two different Tc-Tc distances suggest that different ligands bridge the technetium centers. Since the presence of 7 first shell sulfur neighbors requires that each technetium center has an additional 2 sulfur ligands in addition to those that comprise the $\mathrm{Tc}_{3} \mathrm{~S}\left(\mathrm{~S}_{2}\right)_{3}$ core, possible identities of the bridging ligands are two bridging sulfide (or hydrosulfide) ligands or an edge-bound disulfide similar to the bridging disulfide of the $\mathrm{Tc}_{3}\left(\square^{3}-\mathrm{S}\right)\left(\square-\mathrm{S}_{2}\right)_{3}$ cluster without the Tc-Tc bond. The Tc-Tc distance of two technetium centers symmetrically bridged by an edge-bound disulfide ligand would be close to $4.3 \AA$. In a similar copper complex, ${ }^{33}$ two $\mathrm{Cu}$ centers are separated by $4.03 \AA$, but the Tc-S bonds in $\mathrm{TcS}_{\mathrm{x}}$ are $0.1 \AA$ longer than the $\mathrm{Cu}-\mathrm{S}$ bonds. Moreover, the $\mathrm{S}-\mathrm{S}$ distance of this bridging disulfide, determined from the Tc-Tc and Tc-S distances, is $2.0 \AA$, typical for a bridging disulfide. ${ }^{28,33}$ For these reasons, the $4.3 \AA$ Tc-Tc distance is assigned to two Tc centers symmetrically bridged by a disulfide ligand. 
The $3.85 \AA$ Tc-Tc distance could be due to either two bridging sulfide or hydrosulfide ligands. If the Tc and $\mathrm{S}$ atoms are coplanar, the Tc-Tc and Tc-S distances produce a Tc-S-Tc angle of $109^{\circ}$. Although few families of complexes exist in which the parameters for bridging sulfide and hydrosulfide ligands can be compared directly, a M-S-M angle of $109^{\circ}$ is more typical of a bridging sulfide than of a hydrosulfide, which generally have M-(SH)-M angles of $\sim 100^{\circ} .{ }^{34-36}$ For this reason, the $3.85 \AA$ Tc-Tc distance is assigned to two Tc centers symmetrically bridged by two sulfide ligands. Overall, the EXAFS data is consistent with a $\mathrm{TcS}_{\mathrm{x}}$ structure composed of triangular $\mathrm{Tc}_{3}\left(\square^{3}-\mathrm{S}\right)\left(\square-\mathrm{S}_{2}\right)_{3}$ clusters linked by either bridging disulfide or by two bridging sulfide ligands as shown in Figure 2.

The structure of $\mathrm{TcS}_{\mathrm{x}}$, derived from EXAFS and shown in Figure 2, yields a stoichiometry of $\mathrm{Tc}_{3} \mathrm{~S}_{2}\left(\mathrm{~S}_{2}\right)_{4}$ or $\mathrm{Tc}_{3} \mathrm{~S}_{10}$, which is almost identical to that determined for $\mathrm{Tc}_{2} \mathrm{~S}_{7}$ prepared under similar conditions, $\mathrm{TcS}_{3.2}{ }^{27}$ Since the conditions used to prepare these samples are analogous to those used to prepare $\mathrm{Tc}_{2} \mathrm{~S}_{7}$, it seems likely that $\mathrm{TcS}_{\mathrm{x}}$ is actually $\mathrm{Tc}_{2} \mathrm{~S}_{7}$. However, the technetium centers in $\mathrm{TcS}_{\mathrm{x}}$ are clearly not heptavalent. As dictated by the ligands, $\mathrm{TcS}_{\mathrm{x}}$ is a $\mathrm{Tc}(\mathrm{IV})$ compound, which is consistent with its $\mathrm{Tc}-\mathrm{K}$ edge absorption energy, $6.5 \mathrm{eV}$ below that of $\mathrm{TcO}_{4}^{-}$. For comparison, the energies of the Tc-K edges of $\mathrm{Tc}(\mathrm{IV})$ complexes with oxygen coordination shells occur at $\sim 5.5 \mathrm{eV}$ below that of $\mathrm{TcO}_{4}{ }^{-23}$ Consequently, the technetium sulfide species present in reducing containing grouts, $\mathrm{TcS}_{\mathrm{x}}$, appears to be $\mathrm{Tc}_{2} \mathrm{~S}_{7}$ as previously suggested ${ }^{15,27}$ however, the technetium centers in $\mathrm{TcS}_{\mathrm{x}}$ are tetravalent in agreement with the previous XAFS analysis. $^{14}$

Evolution of technetium speciation determined by XANES spectroscopy. The speciation of technetium in the grout samples was determined by least squares fitting of the XANES spectra using the XANES spectra of $\mathrm{TcO}_{2} \bullet \mathrm{xH}_{2} \mathrm{O}, \mathrm{TcO}_{4}^{-}$, and $\mathrm{TcS}_{\mathrm{x}}$ as components. This method is analogous to those previously described by Ressler et al. and Sarrao et al., which have been shown to yield quantitative speciation information. $^{24,37}$ The evolution of technetium speciation in the unsealed and sealed samples is addressed separately.

Unsealed samples. As described in the previous section, the technetium speciation in all the unsealed samples is initially identical since all samples contain only $\operatorname{TcS}_{\mathrm{x}}$. However, as the samples age, their 
XANES spectra change as shown in Figure 3, which also shows the deconvolution of the XANES spectrum of an aged sample. As is clear from the figure, the agreement between the fit and data is excellent for the unsealed samples. The mole fraction of $\mathrm{TcO}_{4}^{-}$in these samples is reported in Table 3 and shown in Figure 4 as a function of the age of the sample. The scatter of the data shown in Figure 4 is much greater than the error in the measurement and is believed to arise from the spatial inhomogeneity of the technetium speciation in these samples. The origin of this inhomogeneity will be discussed later. Unfortunately, this large degree of scatter results in a correspondingly large standard deviation in the rate of oxidation of Tc(IV) in the samples. The rates of oxidation of the technetium in samples 1-3 are statistically identical, and oxidation of sample 4, which contained no $\mathrm{NO}_{3}^{-}$or $\mathrm{NO}_{2}^{-}$, was slightly faster. The presence of $\mathrm{NO}_{3}{ }^{-}$ and $\mathrm{NO}_{2}{ }^{-}$in these samples did not accelerate the oxidation of the Tc(IV) species.

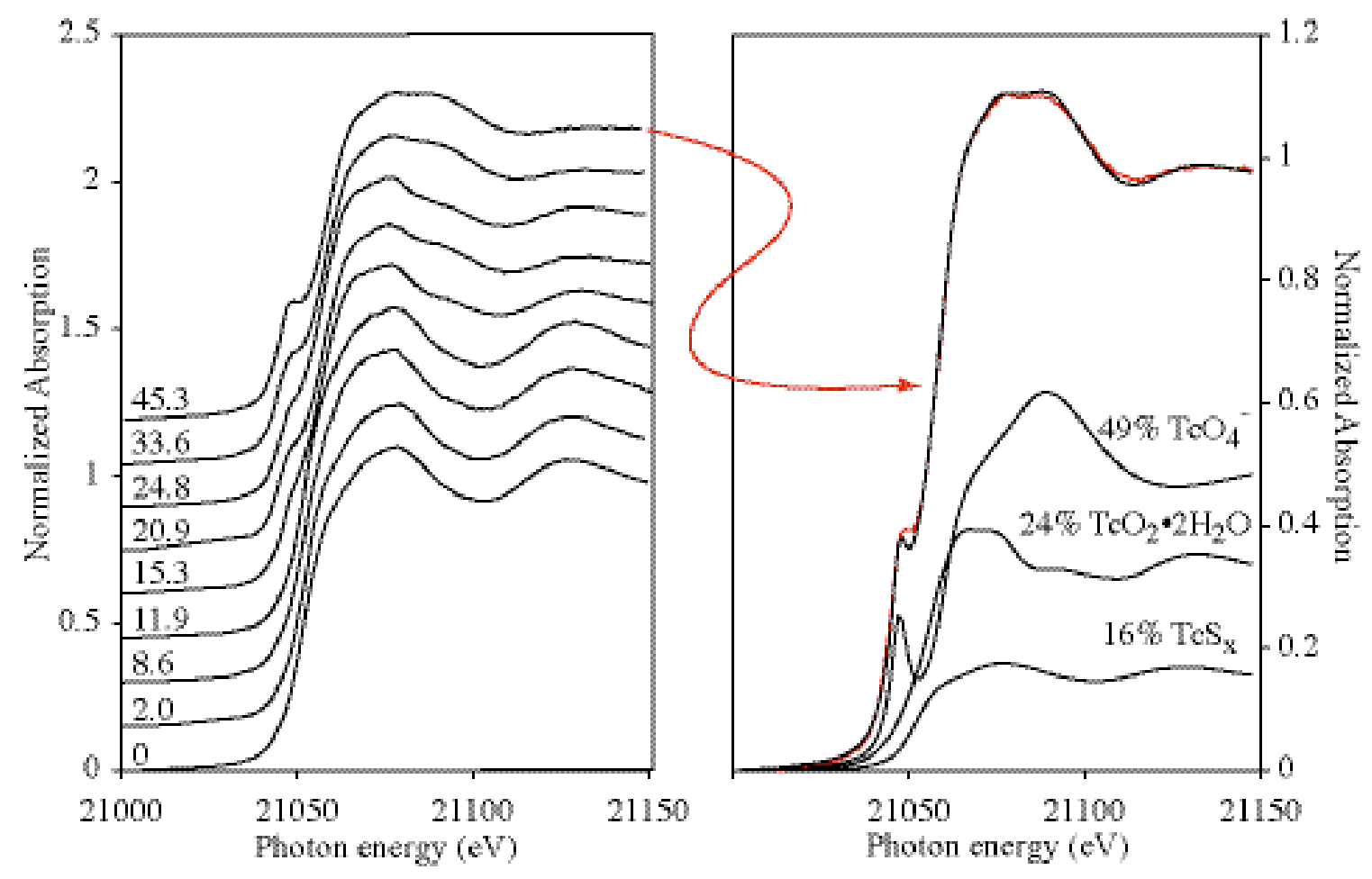

Figure 3: (left) Evolution of the Tc-K edge XANES spectra of unsealed sample 1 as a function of age. The age of cement (in months) is given next to the corresponding spectrum. (right) Deconvolution of the XANES spectrum of a 45 month old sample. Data are shown in red and the least squares fit is shown in black. 
Table 3: Mole fraction of $\mathrm{TcO}_{4}{ }^{-}$in the unsealed samples.

\begin{tabular}{|c|c|c|c|c|}
\hline \multirow{2}{*}{$\begin{array}{l}\text { Age of sample } \\
\text { (months) }\end{array}$} & \multicolumn{4}{|c|}{ Fraction $\mathrm{TcO}_{4}^{-}$(percent) } \\
\hline & Sample 1 & Sample 2 & Sample 3 & Sample 4 \\
\hline 0.0 & $0.00(2)$ & $0.5(4)$ & $0.5(4)$ & $0.4(5)$ \\
\hline 2.0 & 1(1) & $0(2)$ & $0(1)$ & $0(2)$ \\
\hline 8.6 & $0(1)$ & $0(2)$ & $16(2)$ & $0(1)$ \\
\hline 11.9 & $25(2)$ & $0(2)$ & $0(2)$ & $0(2)$ \\
\hline 15.3 & $9(1)$ & $0(5)$ & $23(2)$ & $16(2)$ \\
\hline 20.9 & $7(1)$ & $26(1)$ & $22(1)$ & $31(1)$ \\
\hline 24.8 & $27(2)$ & $1(7)$ & $16(2)$ & $24(1)$ \\
\hline 33.6 & $14(2)$ & $39(1)$ & $32(2)$ & $42(1)$ \\
\hline 45.3 & $38(2)$ & $27(1)$ & $29(2)$ & $49(2)$ \\
\hline $\begin{array}{l}\text { Rate of oxidation } \\
\quad\left(\% \text { month }^{-1}\right)\end{array}$ & $0.7(2)$ & $0.8(3)$ & $0.7(2)$ & $1.3(2)$ \\
\hline
\end{tabular}

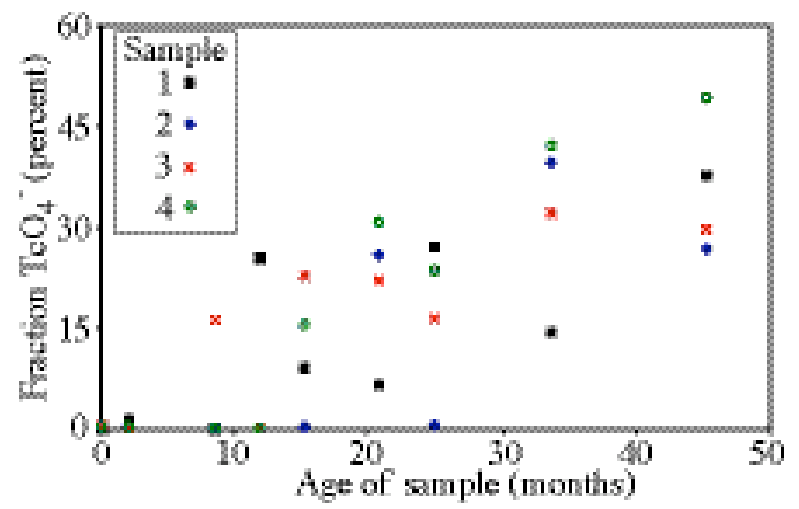

Figure 4: Evolution of the mol. fraction of $\mathrm{TcO}_{4}{ }^{-}$in the unsealed samples as a function of age

Sealed samples. Unlike the unsealed samples, $\sim 20 \%$ of the $\mathrm{TcO}_{4}{ }^{-}$in the sealed samples was not reduced to $\mathrm{Tc}(\mathrm{IV})$ at the beginning of the experiment. However, as the samples aged, the amount of $\mathrm{TcO}_{4}^{-}$ present decreased as shown in Figure 5 and reported in Table 4. The quality of the fit is not as good for these samples as it was for the unsealed samples; however, the errors are small. Unlike the unsealed samples, the sealed samples appear to be spatially homogenous since very little scatter is present in the fraction of $\mathrm{TcO}_{4}{ }^{-}$in these samples and the fraction of $\mathrm{TcO}_{4}{ }^{-}$varies little among the samples until samples $\mathrm{A}$ and $\mathrm{C}$ were exposed to air. The large increase in the amount of $\mathrm{TcO}_{4}{ }^{-}$observed in samples $\mathrm{A}$ and $\mathrm{C}$ at 26 months is due to exposure of these samples to atmosphere at 22 months; sample B remained sealed. As in the unsealed samples, the presence of $\mathrm{NO}_{3}{ }^{-}$has no observable effect on the speciation of technetium. 
Table 4: Evolution of the mol. fraction of $\mathrm{TcO}_{4}{ }^{-}$in the sealed samples

\begin{tabular}{cccc}
\hline $\begin{array}{c}\text { Age of sample } \\
\text { (months) }\end{array}$ & Sample A & $\begin{array}{c}\text { Fraction } \mathrm{TcO}_{4}^{-} \text {(percent) } \\
\text { Sample B }\end{array}$ & Sample C \\
\hline 0.0 & $19(3)$ & $16(3)$ & $20(3)$ \\
5.6 & $15(2)$ & $8(3)$ & $19(3)$ \\
9.5 & $5(2)$ & $4(2)$ & $9(3)$ \\
18.3 & $8(3)$ & $5(2)$ & $9(3)$ \\
30.0 & $41(2)$ & $3(2)$ & $56(2)$ \\
\hline
\end{tabular}

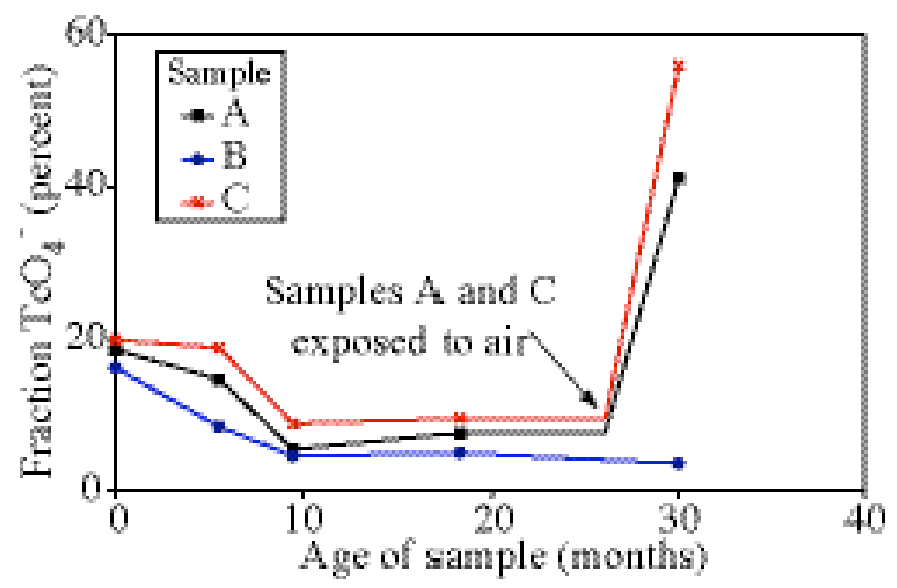

Figure 5: Evolution of the mol. fraction of $\mathrm{TcO}_{4}^{-}$in the sealed samples as a function of age. Arrow indicates when samples $\mathrm{A}$ and $\mathrm{C}$ were opened (the fraction $\mathrm{TcO}_{4}{ }^{-}$at that point is assumed to be the same as previously determined at 18 months).

The data from both series of samples show that $\mathrm{TcS}_{\mathrm{x}}$ in grout is unstable towards oxidation. As noted previously, both $\mathrm{NO}_{3}{ }^{-}$and $\mathrm{O}_{2}$ could oxidize the lower-valent technetium species present in these grout samples. Since the presence of $\mathrm{NO}_{3}{ }^{-}$had no significant effect on the rate of oxidation of technetium in these samples, atmospheric $\mathrm{O}_{2}$ is the likely oxidizing agent. This is also consistent with the spatial inhomogeneity of the technetium speciation present in the unsealed samples. The technetium speciation in the unsealed samples was initially homogenous: all of the technetium in each sample was present as $\mathrm{TcS}_{\mathrm{x}}$. However, as atmospheric $\mathrm{O}_{2}$ diffused into the sample, $\mathrm{TcS}_{\mathrm{x}}$ in the grout near the unsealed top of the cuvette was oxidized, while $\mathrm{TcS}_{\mathrm{x}}$ further down in the sample remained reduced. Therefore, XANES experiments would reveal a different technetium oxidation state depending upon whether grout near the top of the cuvette was examined $\left(\mathrm{TcO}_{4}^{-}\right)$or grout near the bottom was examined $\left(\mathrm{TcS}_{\mathrm{x}}\right)$. The scatter of the data in Figure 4 is consistent with this spatial inhomogeneity of technetium speciation combined with the fact that the portions of the cement examined using XANES were randomly chosen. 
The premise that $\mathrm{O}_{2}$ is the actual oxidizer is strongly supported by the results from the sealed samples illustrated in Figure 5. Although the $\mathrm{TcO}_{4}{ }^{-}$in these samples was not initially reduced to $\mathrm{TcS}_{\mathrm{x}}$, the amount of $\mathrm{TcO}_{4}{ }^{-}$in these samples declined in later months presumably due to reduction by BFS. Furthermore, the technetium speciation in the sealed samples was spatially homogeneous. Although the technetium speciation evolved and the portions of the samples probed by XANES were randomly chosen, little scatter exists in the technetium speciation among the different samples. Since these samples were sealed, atmospheric $\mathrm{O}_{2}$ was not present to oxidize the technetium species near the top of the cuvette, and technetium speciation did not vary with position. The most dramatic evidence for $\mathrm{O}_{2}$ oxidation is the 40-50 $\%$ increase in the amount of $\mathrm{TcO}_{4}{ }^{-}$in the initially sealed samples after 4 months exposure to atmosphere.

One unexpected result is the appearance of $\mathrm{TcO}_{2} \cdot 2 \mathrm{H}_{2} \mathrm{O}$ in the aged samples. Formation of $\mathrm{TcO}_{2} \cdot 2 \mathrm{H}_{2} \mathrm{O}$ cannot result from the hydrolysis of $\mathrm{TcS}_{\mathrm{x}}$ since this compound is stable to hydrolysis under the conditions present during the synthesis of the grout samples. Rather, the observation of $\mathrm{TcO}_{2} \cdot 2 \mathrm{H}_{2} \mathrm{O}$ implies that the oxidation of $\mathrm{TcS}_{\mathrm{x}}$ proceeds by initial oxidation to $\mathrm{TcO}_{2} \cdot 2 \mathrm{H}_{2} \mathrm{O}$ that is then oxidized to $\mathrm{TcO}_{4}{ }^{-}$as shown in equations 2 and 3. This mechanism is consistent with the potentials for the reduction of $\mathrm{SO}_{4}{ }^{2-}$ to $\mathrm{S}^{2-}(-0.67$ $\mathrm{V})$ and of $\mathrm{TcO}_{4}{ }^{-}$to $\mathrm{TcO}_{2} \cdot 2 \mathrm{H}_{2} \mathrm{O}(-0.28 \mathrm{~V})$ at $\mathrm{pH}$ 13. Although the detailed mechanism is more complex than this simple picture, oxidation of $\mathrm{TcS}_{\mathrm{x}}$ to $\mathrm{TcO}_{4}{ }^{-}$proceeds with $\mathrm{TcO}_{2} \cdot 2 \mathrm{H}_{2} \mathrm{O}$ as an intermediate.

$$
\begin{aligned}
& \mathrm{Tc}_{3} \mathrm{~S}_{10}+18 \mathrm{O}_{2}+20 \mathrm{HO}^{-} \mathrm{\square} 3 \mathrm{TcO}_{2} \cdot 2 \mathrm{H}_{2} \mathrm{O}+10 \mathrm{SO}_{4}^{2-}+4 \mathrm{H}_{2} \mathrm{O} \\
& 4 \mathrm{TcO}_{2} \cdot 2 \mathrm{H}_{2} \mathrm{O}+4 \mathrm{HO}^{-}+3 \mathrm{O}_{2} \square 4 \mathrm{TcO}_{4}^{-}+10 \mathrm{H}_{2} \mathrm{O}
\end{aligned}
$$

The thickness of the oxidized region formed in the initially sealed samples after exposure to atmosphere can be determined using a variation of the method used to calculate X-ray self-absorption developed by Tröger, et al. ${ }^{25}$ The observed $40 \%$ increase in $\mathrm{TcO}_{4}{ }^{-}$content over 4 months corresponds to the oxidation of the outer $0.28 \mathrm{~mm}$ of the sample. This thickness can be compared with the thickness of the oxidized region determined using the model developed by Smith and Walton, which is based upon an oxidized region formed by the diffusion and reaction of $\mathrm{O}_{2}$ with the reduced species in CWFs. ${ }^{15}$ In this model, the 
thickness of the oxidized region, $\mathrm{X}$, is determined using equation 4 where $\mathrm{C}_{02}$ is the concentration of dissolved $\mathrm{O}_{2}\left(3 \square 10^{-7} \mathrm{~mol} \mathrm{~mL}^{-1}\right), \mathrm{C}_{\text {red }}$ is the concentration of reducing equivalents in the $\mathrm{CWF}$ in moles of electrons $\left(3.8 \square 10^{-4} \mathrm{~mol} \mathrm{~mL}^{-1}\right.$ for a CWF composed of $28 \%$ BFS with a measured reducing capacity of $\left.0.81 \mathrm{meq} \mathrm{g}^{-1}\right)$, $\mathrm{t}$ is time in $\mathrm{s}, \mathrm{D}_{\mathrm{O} 2}$ is the molar diffusion coefficient of $\mathrm{O}_{2}$ in water $\left(2 \square 10^{-5} \mathrm{~cm}^{2} \mathrm{~s}^{-1}\right)$ and $\mathrm{N}_{\mathrm{m}}$ is the MacMullin number defined above. ${ }^{15}$ The observed thickness, $0.28 \mathrm{~mm}$, of the oxidized region in grout samples exposed to air corresponds to a $\mathrm{N}_{\mathrm{m}}$ of $5.7 \square 10^{-4}$ or a $\mathrm{D}_{\text {eff }}\left(\mathrm{NO}_{3}^{-}\right)$of $8.8 \square 10^{-9} \mathrm{~cm}^{2} \mathrm{~s}^{-1}$, which is within the range of $\mathrm{D}_{\text {eff }}\left(\mathrm{NO}_{3}{ }^{-}\right)$reported for CWFs. The observed rate of oxidation of the grout samples exposed to air is consistent with the simple reaction/diffusion model.

$$
X=\sqrt{\frac{8 N_{m} D_{O 2} C_{O 2} t}{C_{r e d}}}
$$

The effect of oxidation by $\mathrm{O}_{2}$ on an actual waste form, Saltstone, also can be illustrated using this model. In comparison to the grout sample, Saltstone has a smaller $\mathrm{D}_{\text {eff }}\left(\mathrm{NO}_{3}{ }^{-}\right)$, from $1.3 \square 10^{-9} \mathrm{~cm}^{2} \mathrm{~s}^{-1}$ to $5 \square 10^{-9} \mathrm{~cm}^{2}$ $\mathrm{s}^{-1}$, but a similar $\mathrm{C}_{\text {red }}$ since Saltstone is prepared from the same BFS used to prepare the grout samples. Using a $\mathrm{D}_{\text {eff }}\left(\mathrm{NO}_{3}{ }^{-}\right)$of $5 \square 10^{-9} \mathrm{~cm}^{2} \mathrm{~s}^{-1}$, the thickness of the oxidized region would be $17 \mathrm{~cm}$ after one ${ }^{99} \mathrm{Tc}$ half-life $(213,000 \mathrm{yr})$, and after ten half-lives, the oxidized region would be $53 \mathrm{~cm}$ thick. For comparison, the dimensions of a Savannah River Saltstone cell are $30.5 \mathrm{~m} \square 30.5 \mathrm{~m} \square 7.5 \mathrm{~m} .^{7}$ Therefore, approximately $4 \%$ of the technetium in the waste form would be oxidized after one ${ }^{99} \mathrm{Tc}$ half-life, and approximately $14 \%$ would be oxidized after ten half-lives based on the assumption that oxidation occurs at the top and bottom of the Saltstone cell. Cracking and flow of surface water through the CWF could greatly increase these numbers and the leaching of $\mathrm{TcO}_{4}{ }^{-}$by effectively decreasing the size of the Saltstone cell to the intercrack spacing, ${ }^{7,8}$ so this discussion is intended only to illustrate the difference between oxidation by $\mathrm{O}_{2}$, which produces an oxidized surface region with an increased $\mathrm{D}_{\text {eff }}\left({ }^{99} \mathrm{Tc}\right)$, and oxidation by $\mathrm{NO}_{3}^{-}$, which would result in an increased $\mathrm{D}_{\text {eff }}\left({ }^{99} \mathrm{Tc}\right)$ throughout the entire volume of the waste. All of the results in this study indicate that the oxidation of $\mathrm{Tc}(\mathrm{IV})$ species in these grout samples is due solely to $\mathrm{O}_{2}$, and $\mathrm{NO}_{3}{ }^{-}$has no observable effect on the speciation of technetium in these samples. While these results do not show that $\mathrm{NO}_{3}{ }^{-}$is unreactive towards $\mathrm{Tc}(\mathrm{IV})$ in reducing grouts, this reaction occurs too slowly to be observed in this study. 
ACKNOWLEDGMENT. The authors thank Corwin Booth for helpful discussions about least-squares fitting of the XANES data and for the use of the code "fites". The authors thank Christine Langton for providing the pulverized fly ash, BFS, and Portland cement used in this study. This work was supported by the Environmental Management Science Program of the Office of Science and Technology of the U. S. DOE and was performed at the Ernest O. Lawrence Berkeley National Laboratory, which is operated by the U. S. DOE under Contract No. DE-AC03-76SF00098. Portions of this research were carried out at the Stanford Synchrotron Radiation Laboratory, a national user facility operated by Stanford University on behalf of the U.S. Department of Energy, Office of Basic Energy Sciences.

\section{REFERENCES}

(1) Gray, R. H.; Becker, C. D. Environ. Manage. 1993, 17, 461.

(2) "Response to Requirement for Report to Congress Under Floyd D. Spence National Defense Authorization Act for Fiscal Year 2001," Office of River Protection, 2000.

(3) Oblath, S. B. "Relative Release Rates of Nitrate, Tc, Cs, and Sr from Saltstone," DPST-84620, Savannah River Laboratory, 1984.

(4) Oblath, S. B. Environ. Sci. Technol. 1989, 23, 1098.

(5) Serne, R. J.; Lokken, R. O.; Criscenti, L. J. Waste Manage. 1992, 12, 271.

(6) National Research Council. Research Needs for High-Level Waste Stored in Tanks and Bins at U.S. Department of Energy Sites; National Academy Press: Washington, D.C., 2001.

(7) Seitz, R. R.; Walton, J. C.; Dicke, C. A.; Cook, J. R. Mat. Res. Soc. Symp. Proc. 1993, 294, 731.

(8) Kaplan, D. I.; Serne, R. J. Radiochim. Acta 1998, 81, 117.

(9) Gilliam, T. M.; Spence, R. D.; Bostick, W. D.; Shoemaker, J. L. J. Hazard. Mater. 1990, $24,189$.

(10) Taffinder, G. G.; Batchelor, B. J. Environ. Eng. 1993, 119, 17. 
(11) Langton, C. A. "Challenging Applications for Hydrated and Chemically Reacted Ceramics," DP-MS--88-163, Savannah River Laboratory, 1988.

(12) Yeh, B. S.; Wills, G. B. J. Chem. Engin. Data 1970, 15, 187.

(13) Rard, J. A.; Rand, M. H.; Anderegg, G.; Wanner, H. Chemical Thermodynamics of Technetium; Elsevier Science: Amsterdam, 1999.

(14) Allen, P. G.; Siemering, G. S.; Shuh, D. K.; Bucher, J. J.; Edelstein, N. M.; Langton, C. A.; Clark, S. B.; Reich, T.; Denecke, M. A. Radiochim. Acta 1997, 76, 77.

(15) Smith, R. W.; Walton, J. C. Mat. Res. Soc. Symp. Proc. 1993, 294, 247.

(16) Colton, R. The Chemistry of Technetium and Rhenium; Interscience Publishers: New York, 1965.

(17) Bajt, S.; Clark, S. B.; Sutton, S. R.; Rivers, M. L.; Smith, J. V. Anal. Chem. 1993, 65, 1800.

(18) Angus, M. J.; Glasser, F. P. Mat. Res. Soc. Symp. Proc. 1985, $50,547$.

(19) Walden, G. H.; Hammett, L. P.; Chapman, R. P. J. Am. Chem. Soc. 1931, 53, 3908.

(20) Smeller, J. A. Amer. Lab. News 1999, October, 6.

(21) Bucher, J. J.; Allen, P. G.; Edelstein, N. M.; Shuh, D. K.; Madden, N. W.; Cork, C.; Luke, P.; Pehl, D.; Malone, D. Rev. Sci. Instrum. 1996, 67, 4.

(22) Koningsberger, D. C.; Prins, R. X-Ray Absorption: Principles, Applications, Techniques of EXAFS, SEXAFS, and XANES; John Wiley \& Sons: New York, 1988.

(23) Lukens, W. W.; Bucher, J. J.; Edelstein, N. M.; Shuh, D. K. Environ. Sci. Technol. 2002, $36,1124$.

(24) Sarrao, J. L.; Immer, C. D.; Fisk, Z.; Booth, C. H.; Figueroa, E.; Lawrence, J. M.; Modler, R.; Cornelius, A. L.; Hundley, M. F.; Kwei, G. H.; Thompson, J. D.; Bridges, F. Phys. Rev. B 1999, 59, 6855. 
(25) Tröger, L.; Arvanitis, D.; Baberschke, K.; Michaelis, H.; Grimm, U.; Zschech, E. Phys. Rev. B 1992, 46, 3283 .

(26) Cartledge, G. H. J. Electrochem. Soc. 1971, 118, 231.

(27) Lee, S. Y.; Bondietti, E. A. Mat. Res. Soc. Symp. Proc. 1983, 15, 315.

(28) Müller, A.; Pohl, S.; M., D.; Cohen, J. P.; Bennett, J. M.; Kirchner, R. M. Z. Naturforsh. 1979, 34b, 434.

(29) Weber, T.; Muijsers, J. C.; Niemantsverdriet, J. W. J. Phys. Chem. 1995, 99, 9194.

(30) Hibble, S. J.; Rice, D. A.; Pickup, D. M.; Beer, M. P. Inorg. Chem. 1995, 34, 5109.

(31) Cramer, S. P.; Liang, K. S.; Jacobson, A. J.; Chang, C. H.; Chianelli, R. R. Inorg. Chem. 1984, $23,1215$.

(32) Müller, A.; Jostes, R.; Cotton, F. A. Angew. Chem. Int. Ed. Engl. 1980, 19, 875.

(33) Fujisawa, K.; Moro-oka, Y.; Kitajima, N. J. Chem. Soc., Chem. Commun. 1994, 623.

(34) Mueting, A. M.; Boyle, P.; Pignolet, L. H. Inorg. Chem. 1984, 23, 44.

(35) Bianchini, C.; Mealli, C.; Meli, A.; Sabat, M. Inorg. Chem. 1986, 25, 4617.

(36) Pleus, R. J.; Waden, H.; Saak, W.; Haase, D.; Pohl, S. J. Chem. Soc., Dalton Trans. 1999, 2601.

(37) Ressler, T.; Wong, J.; Roos, J.; Smith, I. L. Environ. Sci. Technol. 2000, 34, 950. 